\title{
ANALISIS KERENTANAN BANJIR DI DAERAH ALIRAN SUNGAI (DAS) MEDE KABUPATEN HALMAHERA UTARA
}

\author{
Jorgy Ireng T. Moreng ${ }^{1}$, Murdiyanto ${ }^{2}$, Hilda V. Oroh ${ }^{3}$ \\ ${ }^{1,2,3}$ Program Studi Geografi, Fakultas Ilmu Sosial, Universitas Negeri Manado \\ e-mail: morengjorgy17@gmail.com
}

\begin{abstract}
This study aims to determine the level of vulnerability and the distribution pattern of floods using geographic information system (GIS) analysis. The determination of the level of vulnerability and the distribution pattern of floods is based on a very high level of rainfall, less than 2,838 mm per year, so that there is a potential for flooding to occur. This research was conducted in the Mede Watershed (DAS), North Halmahera Regency. The arithmetic method is used to measure the level of flood vulnerability and flood distribution patterns by determining the interval value. The analysis showed that the less vulnerable areas were 318.92 ha, located in the upstream and downstream parts of the watershed with a percentage of 5.74\%. The upstream and surrounding areas are part of the vulnerable class with an area of 3226.10 ha with a percentage of $57.79 \%$. Meanwhile, those classified as very vulnerable are the downstream area with an area of 2037.06 ha 36.49\%. From the results obtained to control flood events, there must be an arrangement of land use patterns around the Mede watershed.
\end{abstract}

Keywords: Flood Vulnerability, DAS Mede, Arithmetic, GIS

\begin{abstract}
Abstrak: Penelitian ini bertujuan untuk menentukan tingkat kerentanan dan pola sebaran banjir dengan menggunakan analisis Sistem Informasi Geografis (SIG). Penentuan tingkat kerentanan dan pola sebaran banjir di dasarkan atas tingkat curah hujan yang sangat tinggi kurang, yakni lebih dari $2.838 \mathrm{~mm}$ per tahun sehingga dapat berpotensi terjadinya banjir. Penelitian ini dilakukan di Daerah Aliran Sungai (DAS) Mede, Kabupaten Halmahera Utara. Untuk mengukur tingkat kerentanan banjir dan pola sebaran banjir digunakan metode Aritmatika dengan penentuan nilai interval. Hasil analisis menunjukkan daerah yang kurang rentan seluas 318,92 ha yang terletak di bagian hulu dan hilir DAS dengan persentase 5,74\%. Bagian hulu dan sekitarnya merupakan bagian yang memiliki kelas rentan dengan luas yaitu 3226,10 ha dengan persentase 57,79\%. Sedangkan yang tergolong sangat rawan adalah bagian hilir dengan luas wilayah 2037,06 ha 36,49\%. Dari hasil yang di peroleh untuk mengendalikan kejadian banjir, harus adanya penataan pola penggunaan lahan di sekitar DAS Mede.
\end{abstract}

Kata Kunci: Kerentanan Banjir, DAS Mede, Aritmatika, SIG

\section{PENDAHULUAN}

Banjir dalam bahasa populer diartikan sebagai aliran atau genangan air yang menimbulkan kerugian ekonomi atau bahkan menyebabkan kehilangan jiwa, sedangkan dalam istilah teknik diartikan sebagai aliran air sungai yang mengalir melampaui kapasitas tampung sungai tersebut. Hewlett dalam Chay Asdak, (2002).

Banjir yang terjadi di Daerah Aliran Sungai (DAS) Mede Kabupaten Halmahera Utara, pada umumnya bagian selatan DAS Mede berupa pegunungan, bagian dari rangkaian dataran tinggi yang menjadi hulu dan tengah dari DAS tersebut dan juga memiliki banyak Sub-Sub DAS yang menjadi faktor terjadinya banjir, Hilir DAS Mede berada di bagian utara yang bermuara di Teluk Galela. Banjir yang terjadi di DAS Mede Kabupaten Halmahera Utara juga disebabkan oleh aktivitas manusia untuk memenuhi kebutuhan ekonomi. Masyarakat di sekitar DAS Mede memenuhi kebutuhan sehari-hari dengan menebang hutan unuk memperluas lahan agar kebutuhan hidup sehari-hari dapat terpenuhi, sehingga dengan adanya aktifitas di DAS Mede maka dapat menyebabkan hancurnya retensi DAS. Vegetasi di bagian DAS Mede juga sudah semakin berkurang, oleh karena itu ketika turun 